\title{
Recent benthic foraminifers from Tarut Bay, Arabian Gulf coast of Saudi Arabia
}

\author{
M. ABOU-OUF SAYED AHMED \\ Faculty of Marine Science, King Abdulaziz University, Jeddah, Saudi Arabia.
}

\begin{abstract}
Recent bottom sediments from Tarut Bay were studied for their foraminiferal content. 13 of the 43 taxa comprise more than 90 percent of the total living and dead foraminifers. The bay sediments are characterized by a Miliolina-dominated assemblage, Rotaliina constitutes the next abundant suborder, with the Textulariina as a minor part of the fauna. Both living and dead populations exhibit low diversity $(S=1-5)$ due to adverse hydrographic conditions in Tarut Bay.

The foraminiferal species show significant variations between environments. The intertidal zone is dominated by Ammonia beccarii, Quinqueloculina spp., Elphidium, sp. aff. E. advena, Spirolina arietina and Peneroplis planatus. In the shallow subtidal zone $(<3 \mathrm{~m})$, Ammonia beccarii becomes less important and other species of the intertidal zone show significant decreases in their concentrations. Trioculina spp. and Spiroloculina spp. become more abundant. The characteristic feature of the deeper subtidal zone $(>3 \mathrm{~m})$ is the abundance of Eggerelloides scabra, which constitutes $18.5 \%$ of the total foraminifers. Quinqueloculina spp., is the only dominant intertidal taxa to be present as a dominant member of the deeper subtidal zone. Differences in hydrographic conditions and other ecological parameters are considered to be responsible for the species variation. The Quinqueloculina-abundant foraminiferal assemblage of Tarut Bay differs considerably from the foraminiferal assemblages of the southwest Gulf.
\end{abstract}

\section{INTRODUCTION}

The foraminifera of the southern and eastern parts of the Arabian Gulf were first investigated by Henson (1950), and subsequently by Houbolt (1957), Murray (1965a, 1965b, 1966a, b and 1970a, b), Lutze et al. (1971) and Haake (1979). Further cursory notes about the foraminifers have also been included in the discussions on recent carbonate sedimentation in the Gulf. However the Saudi Arabian coastline is still "terra incognita" as far as its foraminiferal fauna is concerned. The only work on the northwestern Gulf is that of Anber (1974), who analysed the foraminiferal content of the sediments off Kuwait. This study was undertaken to complete the picture of the distribution of the foraminifers of the western part of the Arabian Gulf, and to compare these with those of other parts of the Gulf and the Red Sea.

\section{STUDY AREA}

Tarut Bay is located in the central part of the Gulf coast of Saudi Arabia. It represents a transitional region between the open northern coastline which trends roughly NW-SE and is more exposed to the waves generated by the prevailing northerly winds, and the southern coastline trending almost N-S and lying nearly parallel to the direction of the prevailing winds. Tarut Bay is a sheltered shallow, warm, hypersaline environment. It covers an area of about $440 \mathrm{~km}^{2}$, including the small Tarut Island. Most of the bay is shallow with depths of less than $4 \mathrm{~m}$. However, the depth increases towards the eastern part where it reaches depths of 13 metres (Fig.1). Tarut Bay is surrounded by arid regions with high summer temperatures of up to $50 \mathrm{oC}$ and with very low rainfall. Thus the bay receives no significant terrigenous contribution of sediments. The bottom sediments are to a great extent locally produced skeletal and non-skeletal carbonates.

Three sub-environments were identified in Tarut Bay based on the nature of the substrate, vegetation and depth. The intertidal zone is made up of a soft greyish limestone and is generally covered by a veneer of coarse calcareous sediments. The high energy shallow subtidal zone $(3 \mathrm{~m})$ is covered mostly with grey sandy sediments. The deeper subtidal zone $(>3 \mathrm{~m})$ is characterized by relatively finer sediments. Seagrasses occur in irregular patches in both shallow and deeper subtidal zones.

\section{HYDROGRAPHY}

Tarut Bay experiences a diurnal tidal cycle with a range of about 2 metres. The bay is slightly influenced by the northerly winds prevailing in the Gulf. During the study period, the water temperatures in the bay varied from $23.5^{\circ} \mathrm{C}$ to $26.6^{\circ} \mathrm{C}$ without any significant difference between the bottom and surface waters. But Basson et al. (1976) report that the surface temperatures in the Saudi Arabian coastal waters range from $10^{\circ} \mathrm{C}$ in winter to $35^{\circ} \mathrm{C}$ in the summer. Probably the same temperature conditions exist in Tarut Bay. The salinity of the bay waters is higher than that of the open Gulf waters with values ranging from $45 \%$ to $75 \%$ (average $(52 \% 00)$. Maximum salinity was recorded in the inner parts of the northern region (Safwa Bay). In general, the western and northwestern parts of the bay have relatively higher salinities than the open bay waters in the east.

\section{MATERIALS AND METHODS}

During three field trips, spread over 6 months, a total of 121 sediment samples were collected from Tarut Bay (Fig.2) using a 


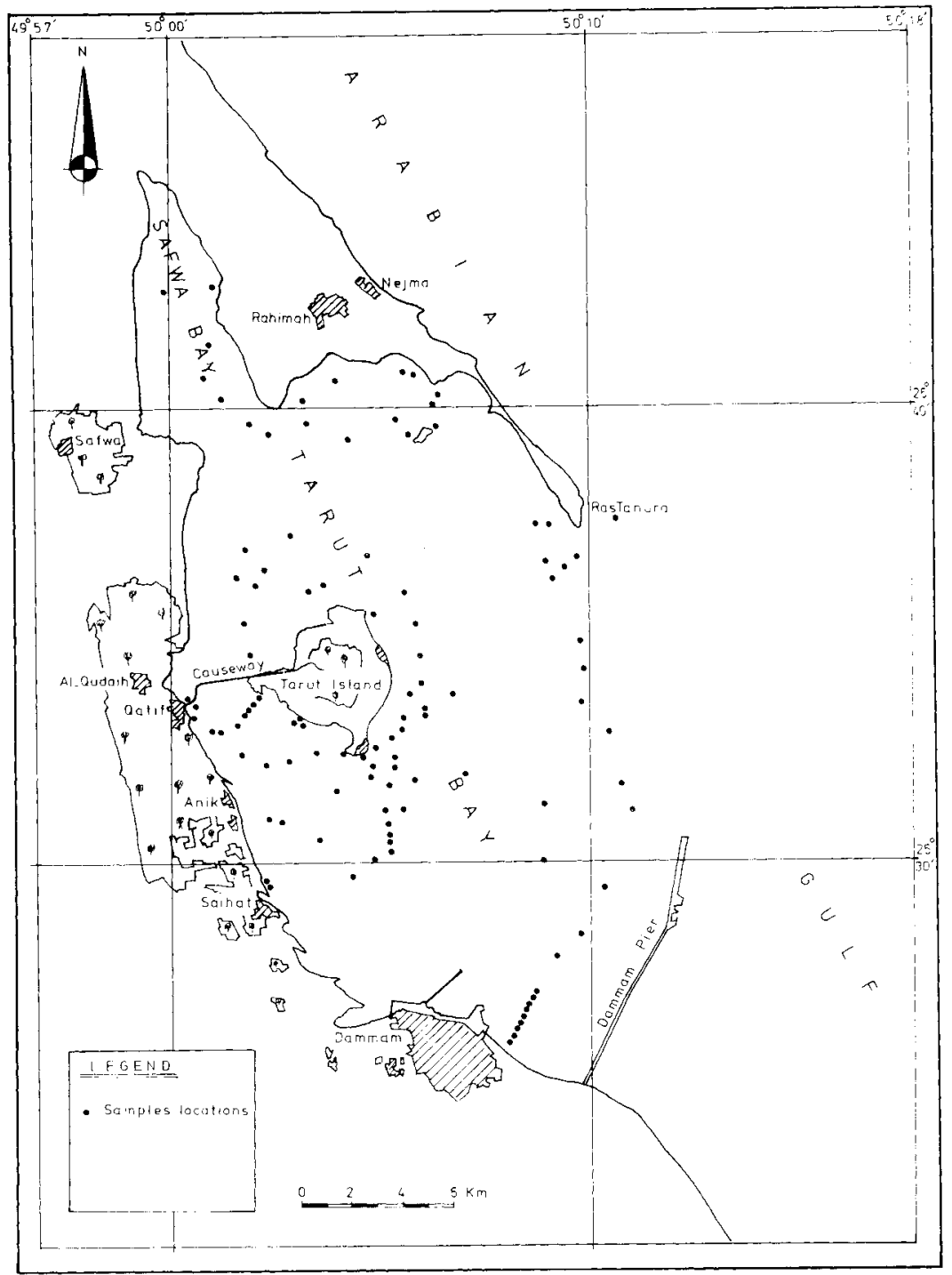

Fig.l. Study area and the location of sediment samples in Tarut Bay.

tray of dimensions $10 \times 10 \times 12 \mathrm{~cm}$ and a van Veen grab $(225 \mathrm{~cm})$. Out of the total, 65 samples were recovered from the hottom with bare sediment and the rest from the areas covered with vegetation. At each location depth was measured by a weighted line subdivided into metres. Immediately after the collection. the sediment samples around Tarut Island were preserved in $10 \%$ neutralized Formalin and the others in $95 \%$ alcohol.

For the foraminiferal analysis, a representative sediment sample was washed over 10 and 200 mesh sieves to remove both gravel and mud. The remaining sand-sized fraction was stained with Rose Bengal (Walton, 1952) to identify the living foraminifers and after one hour washed again over 200 mesh to remove excess stain. Foraminifers were concentrated from the dried sediment by flotation technique using carbon tetrachloride.

As most of the sediments contained high concentrations of foraminifers, a representative sample of $250 \mathrm{mg}$ was spread over a standard picking tray and various taxa of both living and dead foraminifers were identified and counted. The number of percentages of the suborders and of the recognized taxa were calculated for each sample. The data were also used for determining the living/dead ratios (Walton, 1955) and diversity indices (Murray, 1968).

\section{RESULTS AND DISCUSSION}

The living/dead (L/D) ratios of the foraminiters exhibit wide variation from $8 \%$ to $100 \%$. The ratios are randomly distributed in the bay and show no clear relationship with either the nature of the substrate or water depth. Sediments from the seagrass beds have higher as well as lower $\mathrm{L} / \mathrm{D}$ ratios.

The random distribution of the living and dead populations in the bay suggests that prevailing hydrographic conditions or the rate of sedimentation are not controlling the $\mathrm{L} / \mathrm{D}$ ratios. Perhaps 


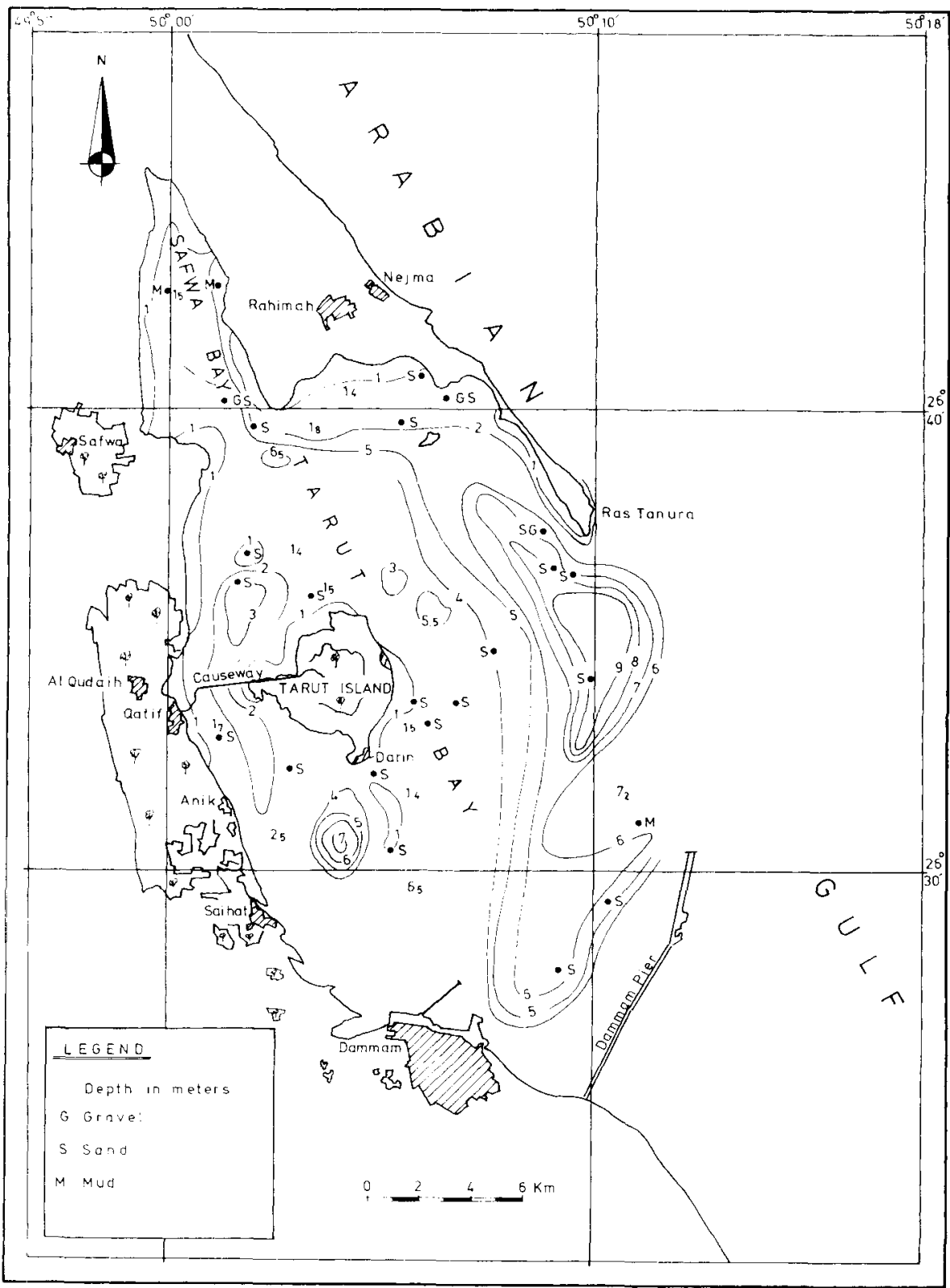

Fig.2. Bathymetry and nature of the substrata in Tarut Bay

the organic matter and oxygen contents in the sediments play a significant role (Said, 1950; Bader, 1952), Even although these parameters were not measured, the generally lower $\mathrm{L} / \mathrm{D}$ ratios in the organic-rich muddy sediments and high $\mathrm{L} / \mathrm{D}$ ratios in the welloxygenated coarse sediments indicate the influence of these factors in determining the $\mathrm{L} / \mathrm{D}$ populations.

The diversity of the foraminifers in Tarut Bay as represented by the Fisher index (Fig.3) is generally low, varying between 1 and 5. These values are slightly lower than those (1-7.5) reported by Murray (1970b) in the Arabian Gulf sediments, and remarkably lower than those (1-13) recorded in Jeddah Bay (Bahafzallah, 1979). In Tarut Bay, higher diversity values are mostly confined to areas covered with seagrass beds and coarse calcareous sands. Even although there is no systematic distribution trend in the diversity of the living and dead foraminifers in the sub-environments, the average number of species varies considerably from one another. In the living foraminifers, the highest number (10) of species occurs in the shallow subtidal zone followed by an average of 7 in the intertidal zone and 6 in the deeper subtidal zone. In contrast, in the dead population, highest numbers of species (18) occur in the deeper subtidal zone, followed by the shallow subtidal (15) and intertidal (12) zones.

The lower diversity values of Tarut Bay are due to the warm hypersaline conditions which prevent colonization of many species living in the normal open sea.

Sugden (1963) and Den Hartog (1970) noticed that the Arabian Gulf in general contains an impoverished Indo-Pacific fauna and flora as a consequence of adverse environmental conditions. Brasier (1975a \& b) recorded high diversity of foraminifers in normal tropical regions and low diversity in hypersaline lagoon habitats. Extreme hydrological conditions 

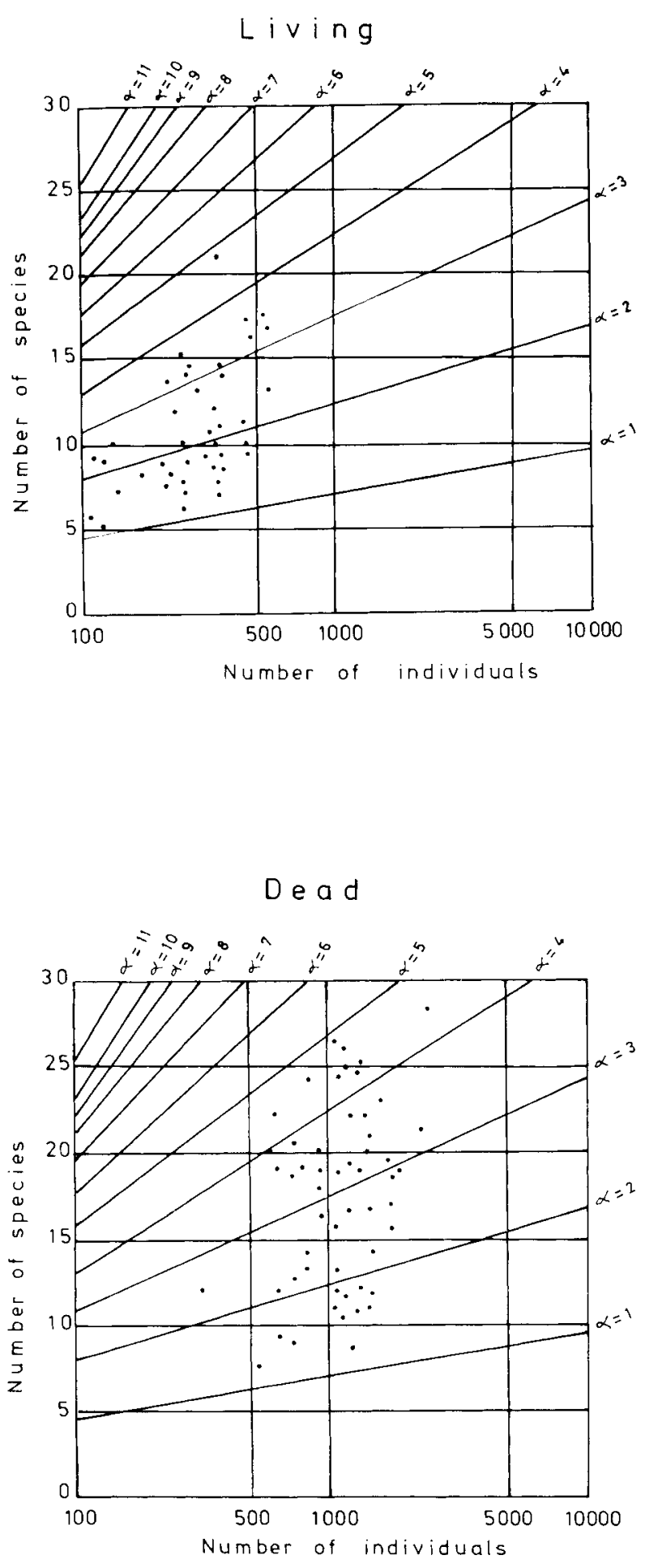

Fig.3 Fisher indices for living and dead foraminifera in Tarut Bay sediments.

were considered to be responsible for the low diversity of the foraminifers in the Abu Dhabi region (Murray, 1970b).

The Tarut Bay sediments are characterized by high Miliolina foraminiferal assemblages typical of shallow water sub-tropical carbonate environments. However, in some sediments between
Qatif and Tarut Island, Rotaliina are relatively more anundant than Miliolina.

Miliolina dominate the living foraminifers with $54.4 \%$ followed by Rotaliina (39.3\%) and Textulariina (6.3\%). An almost similar distribution of the suborders is also noticed in the dead population, except for a considerable drop in the Textulariina content $(3.1 \%)$. The abundances of the three suborders in the living and dead foraminifers of the Tarut Bay sediments are shown in Fig.4. In more than $85 \%$ of the sediments, Rotaliina and Miliolina constitute $90 \%$ of the total foraminifers. Some of the shallow and deep subtidal sediments are enriched with Textulariina. This is particularly more significant in the living population than it is in the dead ones.

Miliolina dominant foraminiferal assemblages are typical of both hypersaline and normal marine tropical and subtropical shallow-water environments (Murray, 1970b, Brasier, 1975b, Bahafzallah, 1979). Therefore Miliolina dominance by itself cannot be taken to indicate hypersaline conditions. The abundance of Miliolina in Tarut Bay can be attributed to the physicochemical conditions, which favour the precipitation of unoriented calcite crystals for Miolina tests rather than oriented crystals for Rotalina tests (Greiner, 1969). The bay is shallow with high

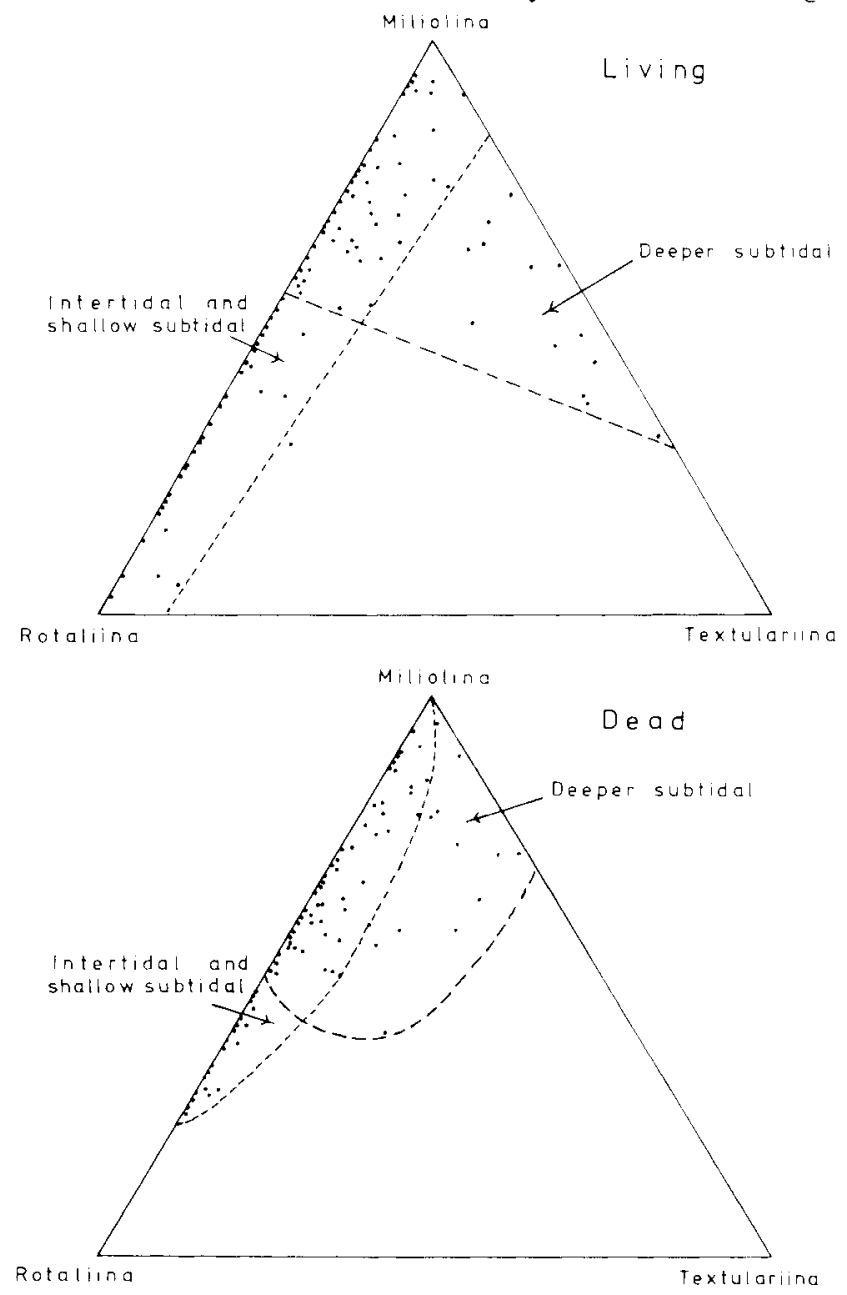

Fig.4 Triangular plot showing the distribution of the three suborders in Tarut Bay sediments. 


\begin{tabular}{|c|c|c|c|}
\hline \multicolumn{4}{|c|}{ Percent $(\%)$} \\
\hline & \multirow[t]{2}{*}{ Foraminiferal species } & \multicolumn{2}{|c|}{ Intertidal zone } \\
\hline & & $L^{*}$ & $\mathrm{Dx}$ \\
\hline 1. & Quinquelocolina spp. & 18.0 & 20.0 \\
\hline 2. & Ammonia beccarii (Linné) & 25.0 & 19.0 \\
\hline 3. & Elphidium sp. aff. E. advend & 17.0 & 18.0 \\
\hline 4. & Triloculina spp. & 4.0 & 4.0 \\
\hline 5 & Spiroloculina spp. & 0.5 & 1.6 \\
\hline 6 & Spirolina arietina (Batsch) & 16.0 & 15.0 \\
\hline$i$ & Peneroplis planatus (Fitchel \& Moll) & 14.0 & 11.0 \\
\hline$\varepsilon$ & Eponides murrayi (Heron, Alen \& Earland) & - & 0.2 \\
\hline 9 & Elphidium reticulosum (Cushman) & 4.0 & 4.0 \\
\hline 10. & Elphidium sp. aff. E. discoidale (d'Orbigny) & 0.5 & 0.8 \\
\hline 11. & Peneroplis pertusus & 0.4 & 1.2 \\
\hline 12. & Textularia spp. & - & - \\
\hline 13. & Eggerelloides scabra (Williamson) & . & - \\
\hline
\end{tabular}

temperatures and the attendant evaporation leads to the supersaturation of $\mathrm{CaCO}_{3}$ within the waters.

In the bottom sediments of Tarut Bay, 43 taxa of forminifers have been recognized. However 13 of these taxa constitute $90 \%$ of the dead and $92 \%$ of the living populations. The relative abundances of the dominant taxa in the subenvironments of the bay are given in Table 1 .

The dominant species of the suborder Miliolina include Quinqueloculina spp. Triloculina spp., Spiroloculina spp.. Spirolina arietina (Batsh), Peneroplis plantus (Fitchel and Moll) and Peneroplis pertusus (Forskal). The suborder Rotalina is mainly composed of Ammonia beccarii (Linne), Elphidium sp alf. advena (Cushman), Eponides murayi (Heron. Allen and Earland) Elphidium sp. aff. discoidale (d'Orbigny). The suborder Textularina is represented by Ammobaculites sp., Tevtularia spp., Bigenerina sp., Eggerelloides scabra (Williamson) and Chavulina spp.

Considering the regional distribution patterns of the major taxa, certain characteristic trends are noticeable. In the living population, the intertidal zone is characterized by a high percentage ( $25 \%$ ) of Ammonia beccarii, which is followed in decreasing order of abundance by Quinqueloculina spp. (18\%), Elphidium sp., aff. E. advena (17\%), Spirolina ariertina $(16 \%)$ and Peneroplis planatus (14\%). On the other hand Eponides murravi. Textularia spp., and Eggerelloides scabra are absent in this zone. The other species constitute only a minor proportion of the total living foraminifers.

In the shallow subtidal zone, Quinqueloculina spp. dominate Ammonia beccarii. There is a significant decrease in the abundance of Elphidilom sp. aff. E. advena and an increase in Spiroloculina spp. and Triloculina spp. compared to the intertidal zone. Another characteristic feature is the appearance of the foraminiferal species that are absent in the intertidal zone.

Quinqueloculina spp. dominate the total living foraminiferal population in the deeper subtidal zone. But Eggerella scabra, Tirloculina spp. and Spiroloculina spp., which are either absent or low in concentration in the intertidal zone and shallow subtidal zone, form the next abundant species. Further there is a remarkable decrease in Ammonia beccarii, Elphidium sp. aff. E. adrenenum. Spirolina ariatina and Peneroplis planatus in the deeper subtidal zone.

\begin{tabular}{llll}
\multicolumn{2}{l}{$\begin{array}{l}\text { Shallow subtidal zone } \\
L\end{array}$} & $D$ & \multicolumn{2}{l}{ Deeper subtidal zone } \\
& & $L$ & $D$ \\
20.0 & 18.0 & 21.0 & 18.0 \\
19.0 & 3.5 & 2.3 & 6.0 \\
9.5 & 11.0 & 0.8 & 2.0 \\
7.0 & 8.0 & 14.8 & 7.0 \\
6 & 8.4 & 10.6 & 13 \\
7.9 & 6.0 & 5.8 & 4.8 \\
8.6 & 6.6 & 1.5 & 2.7 \\
4.0 & 6.0 & 2.0 & 5.2 \\
4.0 & 3.6 & 2.2 & 0.7 \\
2 & 4 & - & - \\
2.0 & 2.0 & 0.7 & 1.2 \\
0.2 & 0.3 & 7.2 & 7.0 \\
1.0 & 0.2 & 18.5 & 3.4
\end{tabular}

Although the percentages of individual species change to some extent, the order of relative abundance of the dead foraminifers closely follows that of the living ones. Further. distribution patterns of the dead foraminiferal species in the subenvironments of Tarut Bay is almost identical to that of the living foraminifers described above.

The varying ecological conditions can be seen in the significant differences in the species assemblages in different parts of the Arabian Gulf. The southwestern Gulf is dominated by peneroplids (Peneroplis pertusus and Spirolina arietina), which are common in Tarut Bay, but which disappear northwards towards Kuwait. These peneroplids have not been recorded from the Iranian side of the Gulf. Ammonia beccarii, which is abundant in Tarut Bay, becomes rare in the Abu Dhabi region, southwestern Gulf. The hydrological variations, which brought about the observed variance in the species assemblage in the Gulf, might have created micro-environments in Tarut Bay. As a consequence the foraminiferal assemblage is not uniform but varies from intertidal to subtidal environments.

\section{ACKNOWLEDGEMENTS}

I wish to express my gratitude to Dr M.C. Keen, Department of Geology \& Applied Geology, University of Glasgow, U.K. for valuable guidance in carrying out this work. Thanks are due to $\mathrm{Dr}$ N.V.N. Durgapresada Rao, Faculty of Marine Science, King Abdulaziz University, Jeddah for suggestions on the preparation of the paper.

Manuscript received December 1989

Revised Manuscript accepted November 1990

\section{REFERENCES}

Anber, S.A., 1974. Foraminifera from offshore area of Kuwait. (North Western Arabian Gulf). Kuwait Universiiy M.Sc Thesis, 1-466.

Bader, R.G., 1952. The role of organic matter in determining the distribution of pelecypods in marine sediment. Jour. Marine Research, 13, 32-47.

Bathafzallah. A.A.K.. 1975. Distribution. ecology and systematics of Recent benthic foraminifera from Jeddah Bay, Red Sea. Unpublished Ph.D. Thesis University of Bristol, 1-219

Basson. Ph., Burchard, J.. Hardy. J. and Price. A.. 1976. Biotopes of the Western Arabian Gulf. Arameo Dept. of Loss Prevention and Environmental Affairs, Dharan, Saudi Arabia, 1-284.

Brasier, M.D. 1975a. Ecology of Recent Sediment-dwelling and Phytal Foraminifera from lagoons of Barbuda, West Indies. J. foramin. Res. 5 (1), 42-62.

Brasier, M.D., 1975b. The ecology and distribution of Recent foraminifers from reefs and shoals around Barbuda. West Indies. J. foramin. Res. 5 (3), 193-210. 
Den Hartog, C., 1970. Sea grass of the World. Verh. K. Ned. Akad. Wet, Afd. Naturk. Tweede Sectic 59 (1), 12-38.

Greiner, G.O., 1969. Recent benthic foraminifers: cnvironmental factors controlling their distribution. Nature 223, 168-170.

Hittke, F.W., 1975. Miliolinen (Foram) in oberflachensedimenten des Persischen Golfes. "Meteor" Forsch-Ergebnisse, C 21, 15-51.

Henson, F.R.S., 1950. Middle eastern Tertiary Peneroplidae (foraminifers) with remarks on the Phylogeny and Taxonomy of the family. West Yorkshire Press Co., Wakefield, 70pp.

Houboldt, J.J., H.C., 1957. Surface sediments of the Persian Gulf near the Qater Pcninsula. State Univ. of Utrecht, Ph.D. Thesis, 1-113.

Iutze, G.F., Grabert, B, and Seibold, E., 1971. Lebendbeobachtungen an Gross Foraminifera (Heterostegina) aus dem Persischen Golf. "Meteor" ForschErgebrisse, Reihe C. 6, 21-40.

Murray, J.W., 1965a. The Foraminiferida of the Persian Gulf, 1. Rosalina adhaerens sp. nov. Ann. Mag. Nat. His. 12, 77-79.

Murray, J.W., 1965b. The Foraminiferida of the Persian Gulf. 2. The Abu Dhabi region. Palaeogeography, palaeoclimatol. palacoecol. 1, 307-332.

Murray, J.W., 1966a. The Foraminiferida of the Persian Gulf. 3. The Halat al Bahrani region. Palaeogeography, palaeoclimatol palaeoecol. 22, 59-68.

Murray, J.W., 1966b. The Foraminiferida of the Persian Gulf, 4. Khor al Bazam. Palaeogeography, palaeoclimatol., palacoecol. 2, 153-169

Murray, J.W., 1966c. The Foraminiferida of the Persian Gulf. 5. The shelf off the Trucial Coast. Palaeogeography, palaeoclimatol, palaeoecol. 2, 267-278.

Murray, J.W., 1967. Production in benthic Foraminiferdis. J. nat. Hist., I, 61-68.

Murray J.W., 1968. Living foraminifera of lagoons and estuaries. Micropaleontology $14,435-455$

Murray, J.W., 1970a. The foraminiferida of the Persian Gulf. 6. Living forms in the Abu Dhabi region. J. nat. Hist. 4, 55-67.

Murray, J.W., 1970b. The Foraminiferida of the hypersaline Abu Dahabi Lagoon, Persian Gulf. Lethaia 3, 51-68.

Said, R., 1950. The distribution of foraminifers in the northern Red Sea. Cushman Found. Foram. Res. Contrib. 1(1-2), 9-29.

Sugden, W., 1963b. Some aspects of sedimentation in the Persian Gulf. J. Sediment. Petrol. 33(2), 355-364

Walton, W.R., 1952. Techniques for recognition of living foraminifers. Cushman Found. Foram. Res. Contrib. 3, 56-60.

Walton, W.R., 1955. Ecology of living benthonic foraminifers. Todos Santos Bay, Baja, Califomia. J. palcont. 20, 952-1018. 